Article

\title{
Hydrogeochemical Assessment of Groundwater Quality of Mokopane Area, Limpopo, South Africa Using Statistical Approach
}

\author{
Mmasabata Dolly Molekoa ${ }^{1}$, Ram Avtar ${ }^{1,2, *}$, , Pankaj Kumar ${ }^{3}$, Huynh Vuong Thu Minh ${ }^{1}$ and \\ Tonni Agustiono Kurniawan ${ }^{4}$ (D) \\ 1 Graduate School of Environmental Science, Hokkaido University, Sapporo 060-0810, Japan \\ 2 Faculty of Environmental Earth Science, Hokkaido University, Sapporo 060-0810, Japan \\ 3 Natural Resources and Ecosystem Services, Institute for Global Environmental Strategies, \\ Hayama 240-0115, Japan \\ 4 Key Laboratory of the Coastal and Wetland Ecosystems (Xiamen University), Ministry of Education College \\ of the Environment and Ecology, Xiamen University, Xiamen 361102, Fujian, China \\ * Correspondence: ram@ees.hokudai.ac.jp; Tel.: +81-011-706-2261
}

Received: 14 July 2019; Accepted: 7 September 2019; Published: 11 September 2019

check for updates

\begin{abstract}
Despite being a finite resource, both the quality and quantity of groundwater are under tremendous pressure due to rapid global changes, viz. population growth, land-use/land-cover changes (LULC), and climate change. The 6th Sustainable Development Goal (SDG) aims to "Ensure availability and sustainable management of water and sanitation for all". One of the most significant dimensions of the SDG agenda is the emphasis on data and governance. However, the lack of good governance coupled with good observed data cannot ensure the achievement of SDG6. Therefore, this study strives to evaluate water quality status and hydrochemical processes governing it in the data-scarce Mokopane area of South Africa. Groundwater is the main source of fresh water supply for domestic usage, intensive agriculture, and mining activities in Mokopane. In this study, hydrogeochemical analysis of groundwater samples was employed to calculate the water quality index (WQI) and evaluate factors governing water quality evolution in the study area. Statistical and spatial analysis techniques were carried out to divide sampling sites into clusters and delineate principal factors responsible for determining water quality of the sampled groundwater. Results suggest that most of the physico-chemical parameters are within permissible limits for drinking water set by the World Health Organization (WHO), except for high fluoride in some samples. $\mathrm{Na}-\mathrm{HCO}_{3}$ is the most abundant water type followed by $\mathrm{Mg}-\mathrm{HCO}_{3}$, which indicates dominance of $\mathrm{Na}^{+}, \mathrm{Mg}^{2+}$, and $\mathrm{HCO}_{3}{ }^{ \pm}$. Rock-water interaction is the prime factor responsible for fluoride enrichment in water. The alkaline nature of groundwater favors the release of exchangeable $\mathrm{F}^{-}$from minerals like muscovite. The WQI suggests that $80 \%$ of water samples fall into the good and excellent categories. Poor management of untreated domestic sewage and agricultural runoff is a main factor for the bad/very bad categories of water samples. As the area lacks any credible scientific/government work to report water quality and its management aspects, the findings of this study will definitely help both scientific communities and policy makers to do what is needed for sustainable water resource management in a timely manner.
\end{abstract}

Keywords: groundwater; geospatial analysis; hydrogeochemical assessment; multivariate statistical analysis; water quality index 


\section{Introduction}

Groundwater is one of the most important finite natural resources for fresh water on Earth [1-3]. Its importance has increased as people depend on it for agriculture and industry, with domestic use exponentially increasing [4-8]. Groundwater exploration and climate change in recent years have led to accelerated depletion of groundwater levels as well as deterioration of groundwater quality, especially in shallow aquifers [9]. Groundwater quality is as important as its quantity, and therefore it is essential to consider in depth the holistic approach towards its management [10]. According to Subramani et al. [11], ground water quality is relatively more important than surface water as it is less susceptible to contamination/pollution and is suitable for different purposes. The quality or physico-chemical characteristics of groundwater is highly dependent on anthropogenic activities like agriculture, mining, urban settlements, etc.; as well as natural processes like rock-water interaction, geological formations, and aerobic/anaerobic conditions of the aquifers [6,12-14]. It is reported that spatio-temporal variation in groundwater quality is also predominantly governed by the hydrogeochemical process occurring at the recharge area and groundwater-surface water interaction [15]. Also, climate change and frequent extreme weather conditions exaggerate the severity of water scarcity [16-18]. Groundwater quality assessment can indicate its suitability for different purposes like drinking and irrigation. The concentration of different chemical parameters beyond their permissible limit leads to serious health complications such as fluorosis, blue baby syndrome, and arsenicosis from fluoride, nitrate, and arsenic, respectively $[19,20]$. Weathering and leaching are the biggest drivers for high fluoride concentration in groundwater [21,22], whereas nitrate enrichment is mainly attributed to agricultural runoff with high usage of fertilizers and leaching from untreated sewerage systems $[7,23]$. Therefore, diligent monitoring is a vital part of groundwater quality management, and thus, for maintenance of healthy aquatic ecosystems and human health [24-26].

Usage of different tools and techniques (e.g., numerical modelling, geographical information systems (GIS)) by both scientific communities and decision makers for groundwater quality assessment and management has rapidly increased over the past few decades [27-30]. A GIS is one of the proven vital tools in studies of groundwater for different purposes (spatial distribution of contaminants, estimating the effect of land-use/land-cover (LULC) changes on water quality, overlay analysis for estimating groundwater potential, etc.) throughout the world [31-35]. In this regard, the use of the water quality index (WQI) can provide simplistic information from complex water quality data to the public and managers. WQI can be used for assessment of surface as well as groundwater quality. Moreover, various WQIs that were developed for irrigation and drinking purposes can help to minimize the adverse effects of water use [6,36]. With the above background, this study focuses on groundwater quality assessment in Mokopane in South Africa using laboratory analysis of water quality parameters well-supported by interpretation through different statistical and GIS tools. This integrated assessment has helped us to understand well the processes governing hydro-geochemical changes in spatial patterns, and hence, the direction for effective management of groundwater resources. The rationale behind choosing this study area is that most of the households in this area rely on groundwater as the sole source of fresh water. However, there are various local reports and complaints relating to groundwater quality deterioration credited to poor sanitation, mining activities, and extensive agriculture in the area [37]. Also, the majority of Mokopane communities rely on pit toilets which have the potential to adversely affect the groundwater quality. Despite the above facts, no detailed scientific study has been conducted to analyze the current status of groundwater quality in the Mokopane. Therefore, this study is an integrated approach (chemical, statistical, spatial analysis) to analyze groundwater quality and processes which are the most likely source of pollutants. 


\section{Study Area}

\subsection{Site Description}

The study area is located in the northern part of Limpopo province of South Africa. Limpopo borders Namibia, Botswana, Zimbabwe, and Mozambique. Mokopane is a town located in the Waterberg district of Limpopo province (Figure 1) with a population of 328,905 in 2016 [38]. It is located at $24^{\circ} 11^{\prime} 2^{\prime \prime} \mathrm{S}$ latitude and $29^{\circ} 0^{\prime} 46^{\prime \prime} \mathrm{E}$ longitude. Figure 2 shows the climatic condition of the study area which falls within steppe climate with mean annual maximum and minimum temperatures of $23.4{ }^{\circ} \mathrm{C}$ and $13{ }^{\circ} \mathrm{C}$ respectively [39]. The average annual rainfall is $490 \mathrm{~mm}$ which normally occurs in November, December, and January. Mokopane has less rainfall during the winter season. July and August are normally dry due to the winter climate.

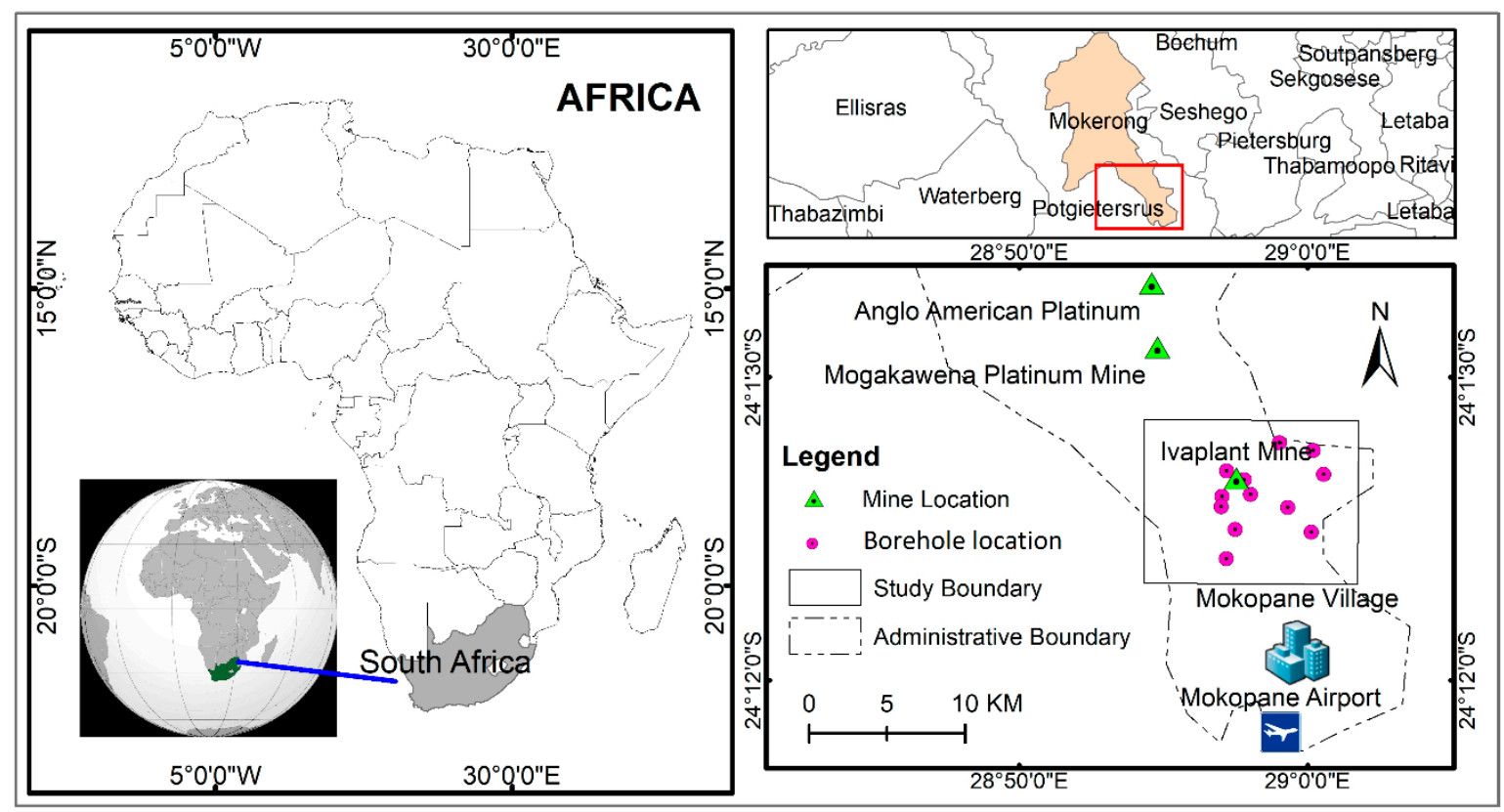

Figure 1. Location of the study area sampling points and mining sites.

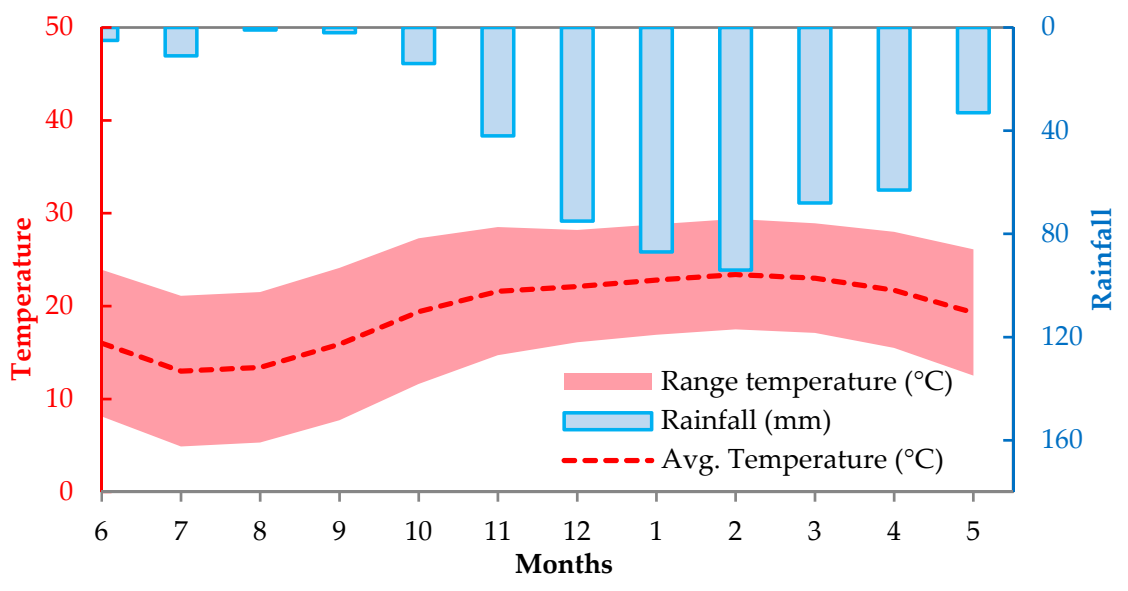

Figure 2. Climate data of average rainfall and temperature in Mokopane.

Economically, Mokopane is known for its intensive agricultural activities until the commencement of Mogalakwena Platinum mine and Ivanplats mine. The mines provide employment to a large portion of the Mokopane population. The Mogalakwena mine is located about $20 \mathrm{~km}$ northwest of Mokopane and Ivanplats mine inside Mokopane area. Geologically the study area has deposit of the Bushveld 
complex. It contains the world's largest reserves of platinum-group minerals (PGMs). The Bushveld Complex comprises the Rustenburg Layered suite, the Lebowa Granites, and the Rooiberg Felsics, that are overlain by the Karoo sediments $[40,41]$. The development of the mining sector in the study area triggered rapid development in informal settlements and, hence, poor domestic sewerage treatment in the area. Poor settlement and sewerage treatment can cause high risks to human health in the near future if these issues are not taken into consideration.

\subsection{Land-Use/Land-Cover Classification}

The LULC map of the study area was prepared using the Landsat 8 satellite image acquired on 16th March 2018. The area was classified into five classes using maximum likelihood classification algorithm in the ENVI 5.2 software (Figure 3). Five classes of LULC map were classified, viz. agriculture land, settlement, vegetation, bare land, and water bodies. The selection of classification classes was based on the field work and other existing maps. Figure 3 shows the LULC maps and locations of the water samples and Ivaplats mining area. Results show that most of the study area was covered with agriculture land (53\%) followed by settlement (32\%), vegetation (13\%), bare land ( $2 \%)$, and water bodies (1\%). Recently, the settlement area has increased in the study area because of the increase in mining activities resulting in high employment opportunities.

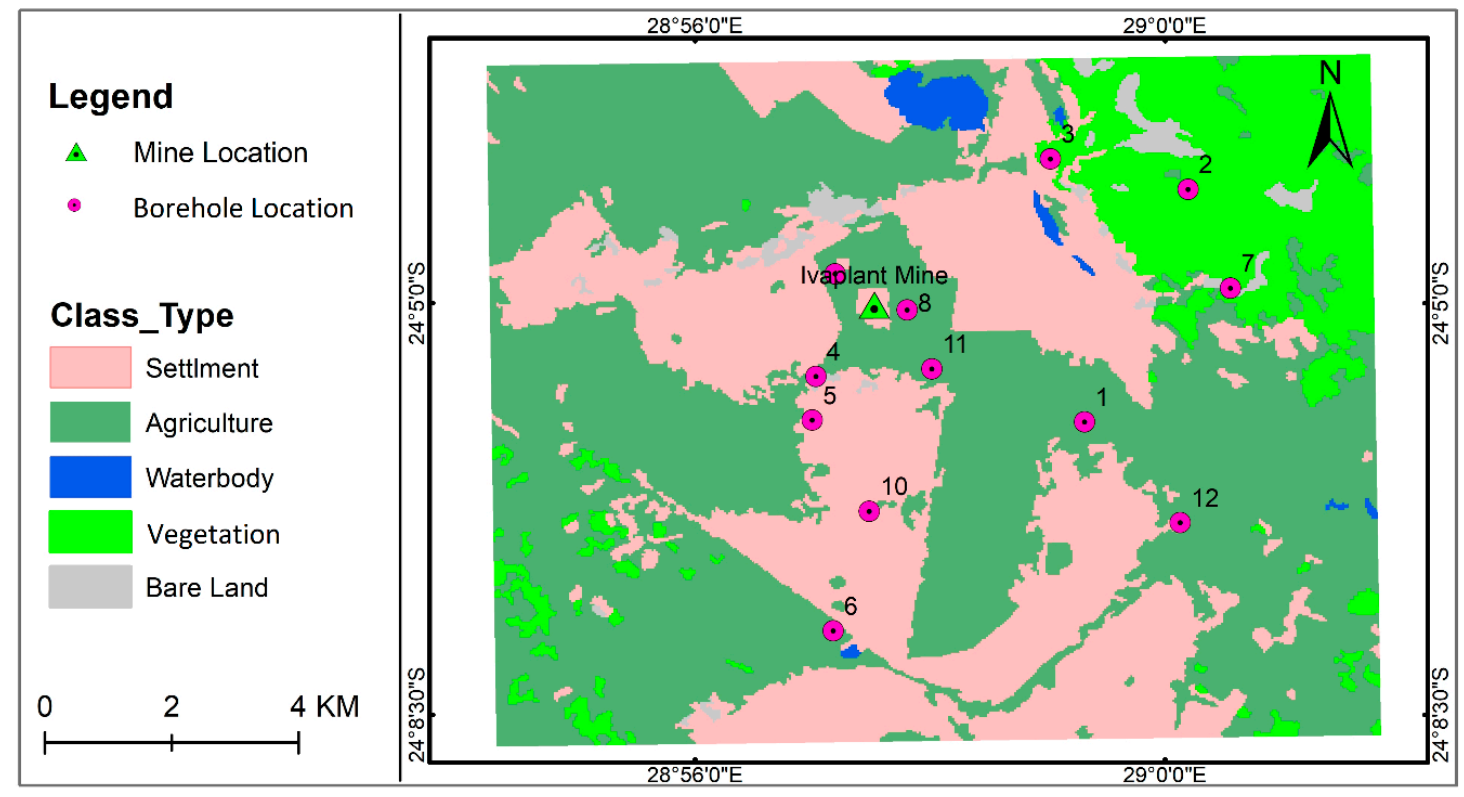

Figure 3. Land-use/land-cover (LULC) map based on Landsat 2018 by using maximum likelihood classification algorithm.

\section{Methodology}

\subsection{Flow Chart of Research Methodology}

Figure 4 shows the flowchart of methodology adopted in this study. Analyzed water quality data was further processed using piper diagram, speciation modeling, groundwater quality index (GWQI) development, statistical analysis, and was well supported by spatial image development. 


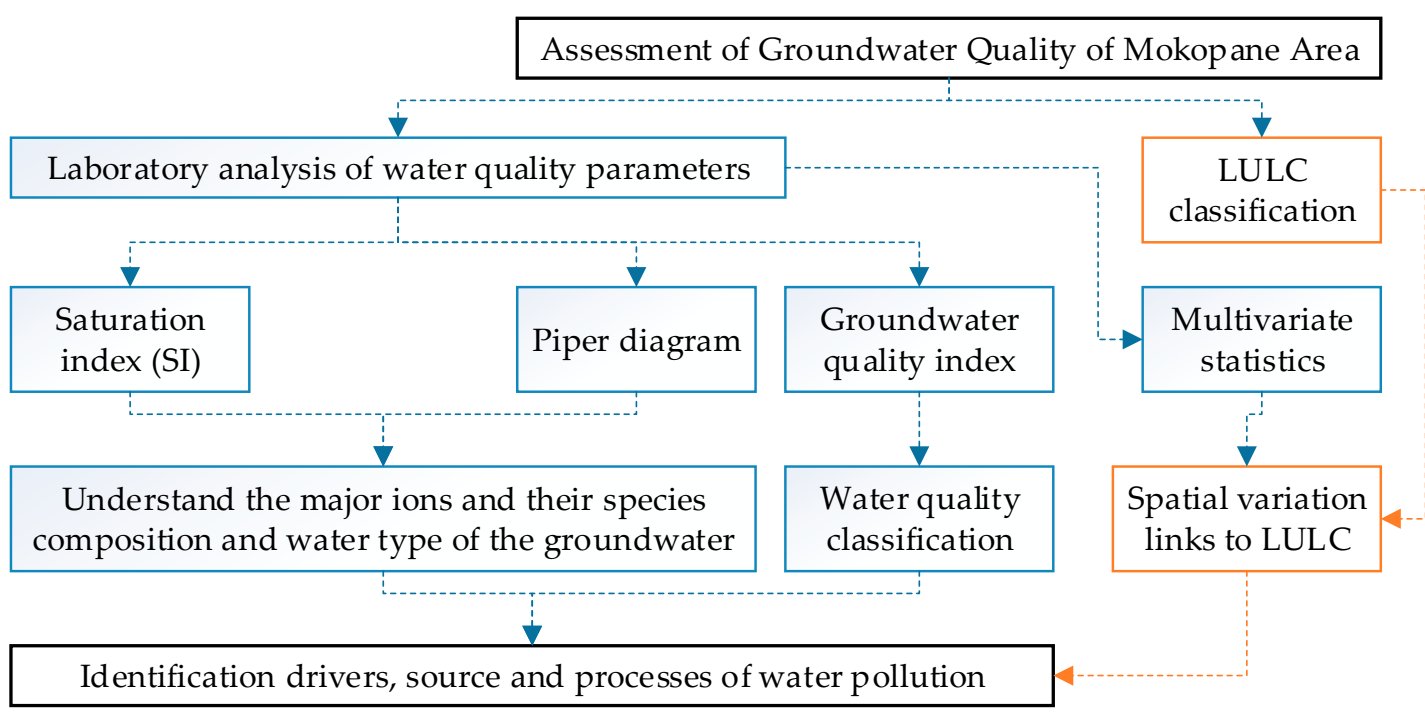

Figure 4. Flowchart of the methodology employed in this study for the assessment of groundwater quality.

\subsection{Sample Collections and Hydrochemical Analysis}

A total of 12 groundwater samples were collected on 12th June 2018 and analyzed for 21 physico-chemical parameters at Capricorn Veterinary Laboratories. Sampling coordinates were recorded using the Global Positioning System (GPS III, Garmin) as shown in Figure 1. The average well depth of groundwater sampling wells is $103.4 \mathrm{~m}$ below ground level (mbgl). Figure 1 shows the locations of the three major mining areas (Ivanplats mine, Mogakawena platinum mine, and Anglo American platinum mine). The inline flow cell that ensures the exclusion of minimized fluctuations and atmospheric contamination was used on-site in order to measure the electrical conductivity (EC) and $\mathrm{pH}$. Precision of $>5 \%$ achieved with the Model Beverly, MA, 01.915, known as the transportable Orion Thermo Water analyzing kit, was used for all kinds of on-site measurements. Collected groundwater samples were stored in thoroughly rinsed polyethylene bottles. In order to stabilize trace metals $(\mathrm{pH} 2)$, the collected samples for major cation analysis were acidified by $1 \% \mathrm{HNO}_{3}$; while samples collected for nitrate were acidified with $\mathrm{H}_{3} \mathrm{BO}_{3}$. The concentration of $\mathrm{HCO}_{3}{ }^{-}$was analyzed by acid titration (using Metrohm Multi-Dosimat); while other anions $\mathrm{Cl}^{-}, \mathrm{NO}_{3}{ }^{-}, \mathrm{SO}_{4}{ }^{2-}$, and $\mathrm{PO}_{4}{ }^{3-}$ were analyzed by DIONEX ICS-90 ion chromatograph with an error percentage of less than $2 \%$ using duplicates. Inductively coupled optical emission spectrometry (ICP-OES) was used to evaluate major cations using duplicates, with a precision of less than $2 \%$. One replicate was used to check the accuracy of the instruments after the analysis of every five samples for each instrument. The analytical precision was checked by the normalized inorganic charge balance (NICB) for major ions. The fractional difference between the total cations and anions is defined as $\left[\left(\mathrm{Tz}^{+}-\mathrm{Tz}^{-}\right) /\left(\mathrm{Tz}^{+}+\mathrm{Tz}^{-}\right)\right]$. Here, $\mathrm{Tz}^{+}$and $\mathrm{Tz}^{-}$represent the total milli-equivalent of cations and anions, respectively. The observed charge balance supports the quality of the data points, which is better than $\pm 8 \%$, and this charge imbalance was generally in favour of positive charge.

\subsection{Statistical Analysis}

Different multivariate statistical tools, viz. cluster analysis (CA) using agglomerative hierarchical clustering (AHC) and principal component analysis (PCA) were applied on the analyzed dataset to find out the interrelationship between the groundwater quality variables and to determine the major factors influencing the groundwater quality $[7,12,14,42-46]$. In addition, the Piper diagram was also used to classify water samples into water types $[46,47]$. 


\subsubsection{Saturation Index for Estimating Groundwater Mineralization}

The saturation index (SI) was calculated in order to understand the origin of groundwater mineralization in the study area. According to Garrels and Christ [48], mineral saturation states with respect to selected minerals were computed as shown by Equation (1).

$$
\mathrm{SI}=\log _{10}\left(K_{I A P} / K_{S P}\right)
$$

where SI is the saturation index, $K_{I A P}$ is the ion activity product of a particular solid phase, and $K_{S P}$ is the solubility product of the phase. Based on the SI values, the saturation states were recognized as saturated (equilibrium; $\mathrm{SI}=0$ ), unsaturated (dissolution; $\mathrm{SI}<0$ ), and oversaturated (precipitation; SI $>0)$.

\subsubsection{Water Quality Index}

This study has used the water quality index (WQI), which has been considered as one of the most reliable tools to classify water contamination levels for both ground and surface water [49]. WQI is based on a scale of 0-300 whereby lower values indicate good water quality, whereas higher values are an indication of contaminated water. Based on the WQI values of $<50,50-100,100-200,200-300$, and $>300$, water samples were categorized as excellent, good, poor, very poor, and unsuitable for drinking, respectively. The following steps were taken in order to calculate WQI:

1. Calculating relative weight: this was calculated using Equation (2).

$$
W_{i}=\frac{w_{i}}{\sum_{i}^{n} w_{i}}
$$

where $W_{i}$ represents the relative weight of each parameter sampled, $w_{i}$ represents the weight of each parameter, and $n$ represents the total number of parameters. All calculated values of $W_{i}$ are shown in Table 1.

2. Calculating $Q$ value: this was calculated using Equation (3).

$$
Q_{i}=\frac{C_{i} \times 100}{S_{i}}
$$

where $Q_{i}$ is quality rating, $C_{i}$ is concentration of each parameter $(\mathrm{mg} / \mathrm{L})$, and $S_{i}$ is derived from the $\mathrm{WHO}$ water quality standard.

3. Finally, WQI was calculated using Equation (4).

$$
W Q I=\sum W_{i} \times Q_{i}
$$

Water quality classification and ratings were designed by Singh et al. [50]. In their paper, they have shown that excellent $\leq 50$, good water $=50-100$, poor water $=100-200$, very poor $=200-300$, and water unsuitable for drinking purpose $\geq 300$. Table 1 shows the relative weights of chemical parameters.

\subsubsection{Spatial Analyses}

In general, asymmetrical distribution of water quality occurred due to water samples being collected from many sites and at different time [51]. To reduce this asymmetry, statistical analysis is one of the methods often used to evaluate water quality variation in many studies in Vietnam, India, and Japan $[7,12,52]$. The various multiple statistical tools, namely, cluster analysis (CA), PCA, factor analysis, and the Piper diagram were useful to differentiate changes in water quality in a spatial pattern $[7,12,52]$. 
Table 1. The relative weight of chemical parameters.

\begin{tabular}{ccccc}
\hline Parameter & Parameter Standard & $Q_{i}$ & Weighted Factor $\left(w_{i}\right)$ & $W_{i}$ \\
\hline $\mathrm{pH}$ & 9.5 & 89.47 & 4 & 0.07 \\
\hline $\mathrm{EC}$ & 150 & 49.67 & 4 & 0.07 \\
\hline $\mathrm{TDS}$ & 1000 & 48.4 & 4 & 0.07 \\
\hline $\mathrm{SS}$ & 25 & 44 & 4 & 0.07 \\
\hline $\mathrm{Ca}$ & 150 & 31.6 & 2 & 0.04 \\
\hline $\mathrm{K}$ & 15 & 64.8 & 2 & 0.04 \\
\hline $\mathrm{Mg}$ & 200 & 34.34 & 2 & 0.04 \\
\hline $\mathrm{Na}$ & 200 & 27.38 & 3 & 0.06 \\
\hline $\mathrm{Cl}$ & 200 & 5.14 & 4 & 0.07 \\
\hline $\mathrm{F}$ & 1.5 & 16 & 5 & 0.09 \\
\hline $\mathrm{NH}_{4}$ & 0.2 & 130 & 5 & 0.09 \\
\hline $\mathrm{NO}_{3}$ & 1 & 34 & 5 & 0.09 \\
\hline $\mathrm{SO}_{4}$ & 400 & 0.58 & 2 & 0.04 \\
\hline $\mathrm{Si}$ & 22.39 & 3 & 0.06 \\
\hline $\mathrm{PO}_{4}$ & 9.2 & 0.50 & 2 & 0.04 \\
\hline $\mathrm{COD}_{\mathrm{Sum}}$ & 10 & 24 & 3 & 0.06 \\
\hline & 75 & & 54 & 1 \\
\hline
\end{tabular}

\subsection{Mapping Spatial Distribution of Groundwater Quality}

Inverse distance weighting (IDW) interpolation is a geospatial method to see the spatial distribution of groundwater quality parameters. This interpolation method was developed by Shepard, Bartier, and Keller $[53,54]$. Although the IDW method contains a "bull's eye" which has an effect on concentric regions of the same value near the known points [55], IDW is based on the distance-weighting exponent which can precisely control the influence of the distance of the points [54]. The IDW interpolation method was used to see the spatial distribution of groundwater quality in Mokopane using ArcGIS 10.3 software.

\section{Results and Discussion}

\subsection{General Groundwater Chemistry}

A statistical summary of the groundwater quality is presented in Table 2 . The $\mathrm{pH}$ values of the groundwater samples varied from 7.31 to 9.24 with an average value of 8.30, suggesting the alkaline nature of groundwater. The alkaline nature of groundwater also suggests enhanced dissolution due to the interaction between soil and rainwater [56]. In addition, the alkaline aquifer condition depicts the influence of an arid/semiarid climate with relatively low rainfall and high evaporation. The electrical conductivity of groundwater varied from $728.0-1895.0 \mu \mathrm{S} / \mathrm{cm}$ with an average value of $1022.17 \mu \mathrm{S} / \mathrm{cm}$ indicating high ionic activity in the area. This also suggests soil mineralization or salt deposition due to climatic conditions as supported by high $\mathrm{pH}$. Looking into the analyzed water quality data for major ions, anionic abundance was in the order of $\mathrm{HCO}_{3}{ }^{-}>\mathrm{Cl}^{-}>\mathrm{SO}_{4}{ }^{2-}>\mathrm{CO}_{3}{ }^{2-}>\mathrm{NO}_{3}{ }^{-}>\mathrm{F}^{-}>$ $\mathrm{PO}_{4}{ }^{3-}$, while cationic abundance was found in the order of $\mathrm{Na}^{+}>\mathrm{Mg}^{2+}>\mathrm{Ca}^{2+}>\mathrm{K}^{+}$. The highest average concentration of $\mathrm{HCO}_{3}{ }^{-}$among anions is due to the presence of carbonaceous sandstones in the aquifers and weathering of carbonate minerals in rain water followed by subsequent precipitation of $\mathrm{HCO}_{3}{ }^{-}$along with other cations. Higher $\mathrm{Cl}^{-}$and $\mathrm{SO}_{4}{ }^{2-}$ concentration also categorized as secondary salt mainly came from the leaching of sewage effluent, especially due to poor sewage management in the informal settlements. In addition, higher concentrations of $\mathrm{SO}_{4}{ }^{2-}$ can also be attributed to the leaching of organic matter and agricultural runoff carrying unutilized $\mathrm{SO}_{4}{ }^{2-}$. Concentration of $\mathrm{NO}_{3}{ }^{-}$ 
and $\mathrm{PO}_{4}{ }^{3-}$ is not of concern as it is well below the permissible WHO limits for all groundwater samples. Concentration of $\mathrm{F}^{-}$varied from 0.24 to $3.39 \mathrm{mg} / \mathrm{L}$. Sporadic fluoride contamination, i.e., $>1.5 \mathrm{mg} / \mathrm{L}$ permissible limit set by $\mathrm{WHO}$, for some of the groundwater samples is a matter of concern and puts the local people at moderate risk of fluorosis (tooth decay particularly in children and bone deformation) if consumed for longer periods of time and not given timely attention for its remediation. For cations, $\mathrm{Na}^{+}>\mathrm{Mg}^{2+}>\mathrm{Ca}^{2+}>\mathrm{K}^{+}$and the average milli-equivalent ratio of $\mathrm{Na}^{+}+\mathrm{K}^{+} / \mathrm{Mg}^{2+}+\mathrm{Ca}^{2+}$ was found to be 1.08 , indicating the prominence of both alumina-silicate and carbonaceous weathering in the study area.

Table 2. Statistical summary of groundwater quality in the study area.

\begin{tabular}{|c|c|c|c|c|}
\hline Parameter & Range & Average & St Dev & $\begin{array}{l}\text { WHO Permissible Limit } \\
\text { (WHO, 2011) }\end{array}$ \\
\hline $\mathrm{pH}$ & $7.31-9.24$ & 8.30 & 0.79 & - \\
\hline Depth (mbgl) & $60.0-169.0$ & 103.42 & 33.3 & - \\
\hline Temp. $\left({ }^{\circ} \mathrm{C}\right)$ & $25.40-26.3$ & 25.8 & 0.25 & - \\
\hline $\mathrm{TH}(\mathrm{mg} / \mathrm{L})$ & $81.62-440.46$ & 269.52 & 105.0 & 50 \\
\hline $\mathrm{EC}(\mu \mathrm{s} / \mathrm{cm})$ & 728.0-1895 & 1022.17 & 333.54 & - \\
\hline TDS (mg/L) & $473.00-1232$ & 664.25 & 216.84 & - \\
\hline $\mathrm{SS}(\mathrm{mg} / \mathrm{L})$ & $10.00-42$ & 21.50 & 12.11 & - \\
\hline $\mathrm{HCO}_{3}{ }^{-}(\mathrm{mg} / \mathrm{L})$ & $162.50-544.6$ & 346.67 & 106.81 & - \\
\hline $\mathrm{CO}_{3}{ }^{2-}(\mathrm{mg} / \mathrm{L})$ & $0.00-119.2$ & 41.32 & 43.96 & - \\
\hline $\mathrm{Ca}^{2+}(\mathrm{mg} / \mathrm{L})$ & $2.50-53.02$ & 19.65 & 19.00 & 200 \\
\hline $\mathrm{K}^{+}(\mathrm{mg} / \mathrm{L})$ & $1.46-9.72$ & 3.45 & 2.35 & 200 \\
\hline $\mathrm{Mg}^{2+}(\mathrm{mg} / \mathrm{L})$ & 7.64-100.54 & 53.75 & 24.86 & 150 \\
\hline $\mathrm{Na}^{+}(\mathrm{mg} / \mathrm{L})$ & $47.32-329.76$ & 133.58 & 75.15 & 200 \\
\hline $\mathrm{Mn}(\mathrm{mg} / \mathrm{L})$ & $0.01-0.48$ & 0.11 & 0.15 & 1 \\
\hline $\mathrm{Cl}^{-}(\mathrm{mg} / \mathrm{L})$ & 7.21-188.19 & 83.24 & 50.76 & 600 \\
\hline $\mathrm{F}^{-}(\mathrm{mg} / \mathrm{L})$ & $0.24-3.39$ & 1.35 & 0.98 & 1.5 \\
\hline $\mathrm{NH}_{4}{ }^{+}(\mathrm{mg} / \mathrm{L})$ & $0.19-0.89$ & 0.48 & 0.32 & 25 \\
\hline $\mathrm{NO}_{3}{ }^{-}(\mathrm{mg} / \mathrm{L})$ & $0.06-19.96$ & 4.99 & 8.09 & 50 \\
\hline $\mathrm{PO}_{4}{ }^{3-}(\mathrm{mg} / \mathrm{L})$ & $0.01-0.01$ & 0.01 & $1.81 \mathrm{E}-18$ & 50 \\
\hline $\mathrm{SO}_{4}{ }^{2-}(\mathrm{mg} / \mathrm{L})$ & $2.01-203.18$ & 44.79 & 58.44 & 400 \\
\hline $\mathrm{Si}(\mathrm{mg} / \mathrm{L})$ & $0.43-36.46$ & 10.12 & 12.75 & - \\
\hline
\end{tabular}

TH-Total hardness, EC—Electric Conductivity, TDS—Total dissolved solid, SS—suspended solid, mbgl—meter below ground level.

The concentrations of most of the parameters were found to be well within the permissible limits set by the WHO (2011) except for $\mathrm{F}^{-}$and $\mathrm{Na}^{+}$for few samples. High concentration of $\mathrm{Na}^{+}$in groundwater samples causes only scale formation in the pipelines due to high hardness of the water but does not cause any health effect to the consumers. Potential sources of high $\mathrm{Na}^{+}$are alumino-silicate weathering like schist, granitic rocks containing $\mathrm{Na}^{+}$, and cation-exchange $\mathrm{Na}^{+} / \mathrm{K}^{+}$with $\mathrm{Ca}^{2+} / \mathrm{Mg}^{2+}$. On the other hand, as high concentration of $\mathrm{F}^{-}$in the groundwater (i.e., $>1.5 \mathrm{mg} / \mathrm{L}$ ) causes fluorosis (dental, skeletal), further investigation was made about it. It was found that $75 \%$ of the water samples contain $\mathrm{F}^{-}$concentration less than $1.5 \mathrm{mg} / \mathrm{L}$, hence the water is safe to drink or use for cooking. The rest of the water samples were categorized under low risk $\left(17 \%\right.$ with $\mathrm{F}^{-}$concentration between 1.5 to $2.9 \mathrm{mg} / \mathrm{L}$ ) and high risk (8\% with $\mathrm{F}^{-}$concentration between $3.0-5.0 \mathrm{mg} / \mathrm{L}$ ).

The fluoride ion $\left(\mathrm{F}^{-}\right)$normally remains non-reactive for groundwater with $\mathrm{pH} \leq 7.0$ because of its low solubility and remains absorbed in clay or exchangeable materials. However, once the $\mathrm{pH}$ of groundwater goes beyond 7.0 (i.e., alkaline medium), the hydroxyl group $\left(\mathrm{OH}^{-}\right)$group replaces the 
exchangeable fluoride from silicate minerals like biotite, muscovite etc. resulting in fluoride enrichment. The whole chemical process can be explained for muscovite using Equation (5).

$$
\mathrm{KAl}_{2}\left[\mathrm{AlSi}_{3} \mathrm{O}_{10}\right] \mathrm{F}_{2}+2 \mathrm{OH}^{-} \rightarrow \mathrm{KAl}_{2}\left[\mathrm{AlSi}_{3} \mathrm{O}_{10}\right]\left[\mathrm{OH}_{2}\right]+2 \mathrm{~F}^{-}
$$

Another possible chemical reaction, where hydrolysis of alumina-silicate minerals produces bicarbonate ions, which can enhance fluoride dissolution, is calculated using Equations (6) and (7).

$$
\begin{gathered}
\mathrm{NaAlSi}_{3} \mathrm{O}_{8}+\mathrm{H}_{2} \mathrm{CO}_{3}+\mathrm{H}_{2} \mathrm{O} \rightarrow \mathrm{Na}^{+}+\mathrm{HCO}_{3}^{-}+2 \mathrm{H}_{4} \mathrm{SiO}_{4}+2 \mathrm{Al}_{2} \mathrm{Si}_{2} \mathrm{O}_{5}(\mathrm{OH})_{4} \\
\mathrm{CaF}_{2}+2 \mathrm{HCO}_{3}^{-} \rightarrow \mathrm{CaCO}_{3}+2 \mathrm{~F}^{-}+\mathrm{H}_{2} \mathrm{O}+\mathrm{CO}_{2}
\end{gathered}
$$

IDW interpolation was used to show the spatial distribution of $\mathrm{SO}^{2-}$ and $\mathrm{F}^{-}$as shown in Figure 5. The high concentration of $\mathrm{F}^{-}$was observed in boreholes 2,3 , and 7, where it exceeded the permissible limit of $1.5 \mathrm{mg} / \mathrm{L}$. On the other hand, high SO $4^{2-}$ concentration was observed in boreholes 8,9 , and 11 . To further support its origin, speciation modelling for minerals related to fluoride was conducted. This is discussed later in the manuscript.

To further strengthen our findings, the depth profile of $\mathrm{F}^{-}$and $\mathrm{SO}_{4}{ }^{2-}$ is plotted and shown in Figure 6. It is found that $\mathrm{F}^{-}$concentration has a significant association with groundwater well depth. Its concentration is generally higher for groundwater samples from higher well depths. This supports the ideas of geogenic origin as presented above. On the other hand, the higher concentration of $\mathrm{SO}_{4}{ }^{2-}$ is found in groundwater samples with shallow well depths. As anthropogenic activities are also potential sources for $\mathrm{SO}_{4}{ }^{2-}$, it can be expected that leaching of untreated and unmanaged domestic sewage will contaminate shallow aquifers first, thus firmly supporting the findings.

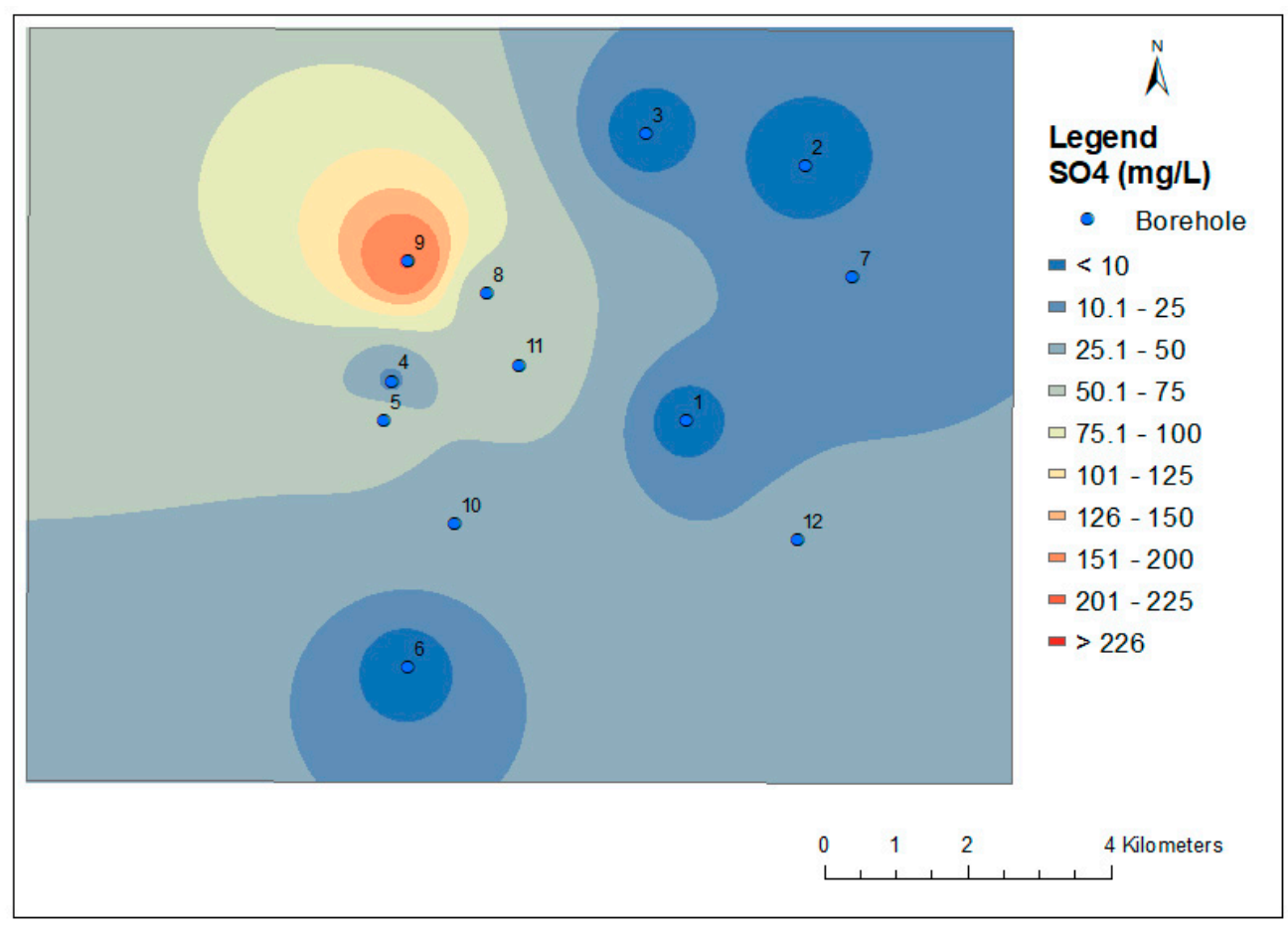

Figure 5. Cont. 


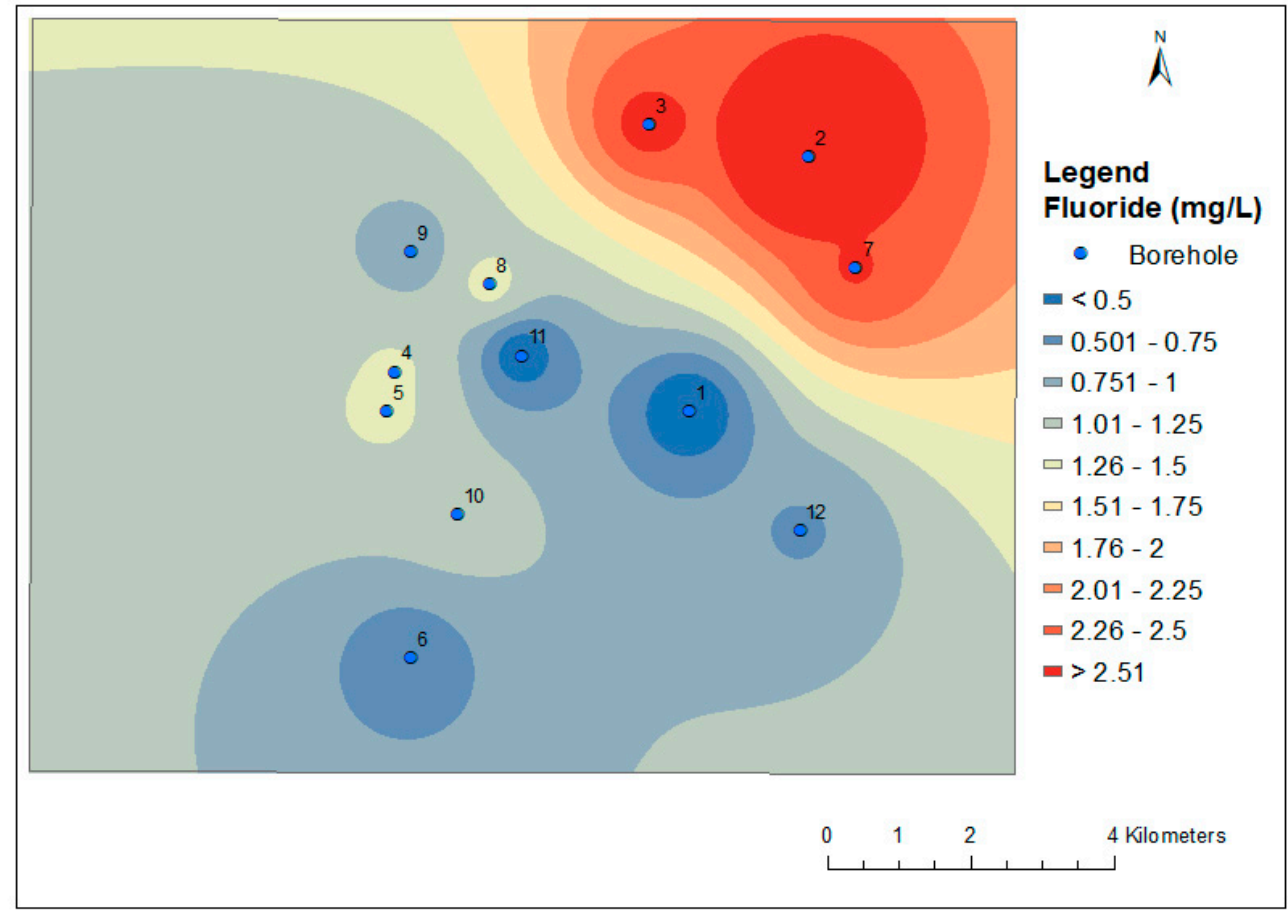

Figure 5. Spatial distribution of sulphate and fluoride using inverse distance weighting (IDW) interpolation in the study area.
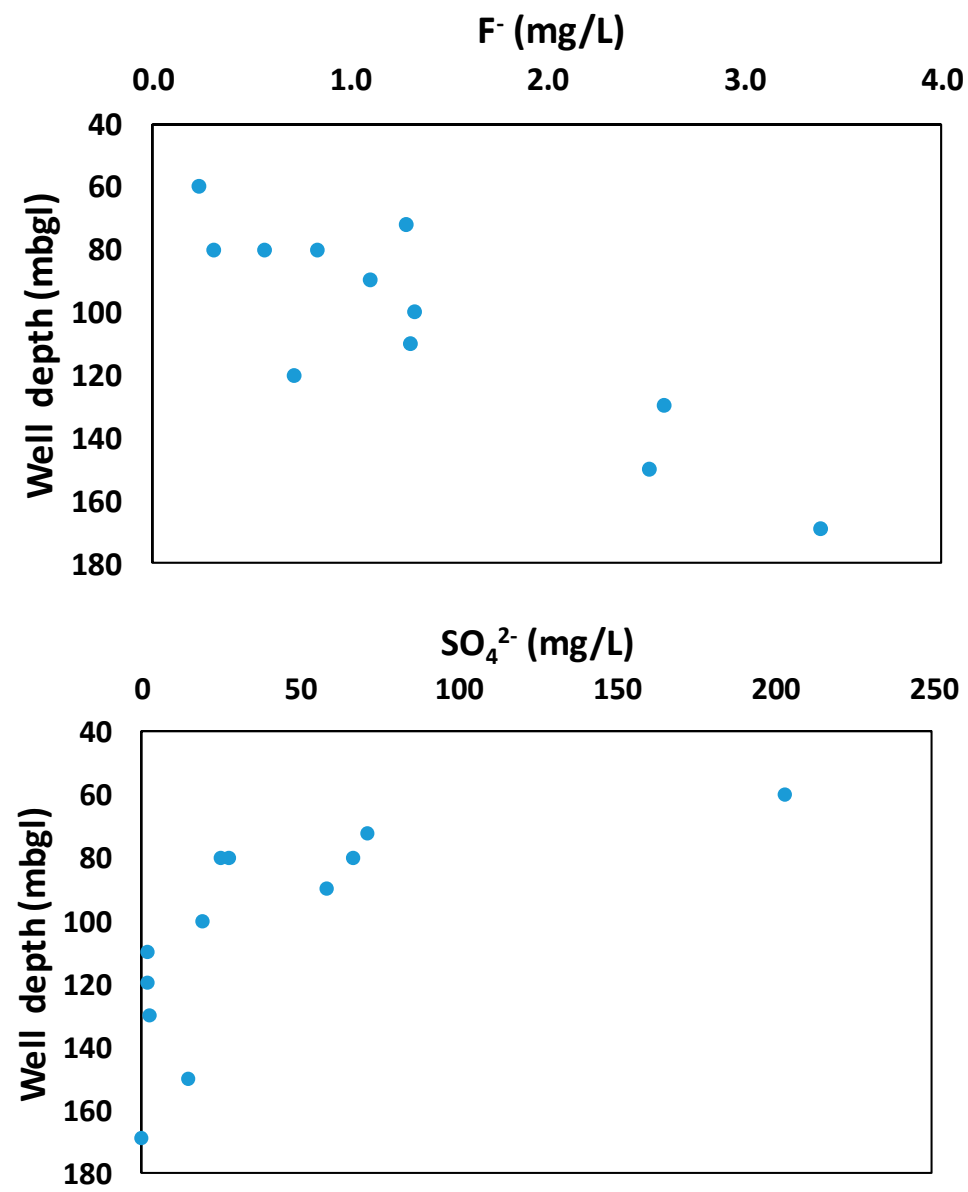

Figure 6. Scatter plot showing depth profile for $\mathrm{F}^{-}$and $\mathrm{SO}_{4}{ }^{2-}$. 


\subsection{Graphical Presentations of Water Quality Data}

In this study, physico-chemical data were further analyzed using the Piper diagram to get a deep insight into hydro-chemical processes controlling water quality of groundwater samples. The water type was calculated by plotting major cations and anions in the Piper diagram as shown in Figure 7. All water samples fell under three water facies, i.e., $\mathrm{Na}-\mathrm{HCO}^{3}(50 \%), \mathrm{Mg}-\mathrm{HCO}^{3}(42 \%)$, and $\mathrm{Na}-\mathrm{Cl}$ $(8 \%)$. These water facies show chemical reactions during rock-water interaction within lithological context. Results indicate the dominance of weak acids (i.e., $\mathrm{HCO}^{3}$ ) over hard acids (i.e., $\mathrm{SO}^{4}$ and $\mathrm{Cl}$ ). Also, ion exchange, dissolution of magnesite, semi-arid/arid climate, alkaline conditions as well as alumina-silicate/carbonate weathering are responsible for high concentrations of $\mathrm{Na}^{+}, \mathrm{Mg}^{2+}$ and $\mathrm{HCO}_{3}{ }^{-}$. However, with poor management of pollution sources like untreated sewerage and agricultural runoff, there is a migration tendency from bicarbonate pole to the chloride pole. In addition, the effect of pit toilets still in practice for several local communities in the study area cannot be neglected. Henceforth, a further detailed investigation of microbial colonies (in particular, E. coli or fecal coliform) is a matter of research priority.
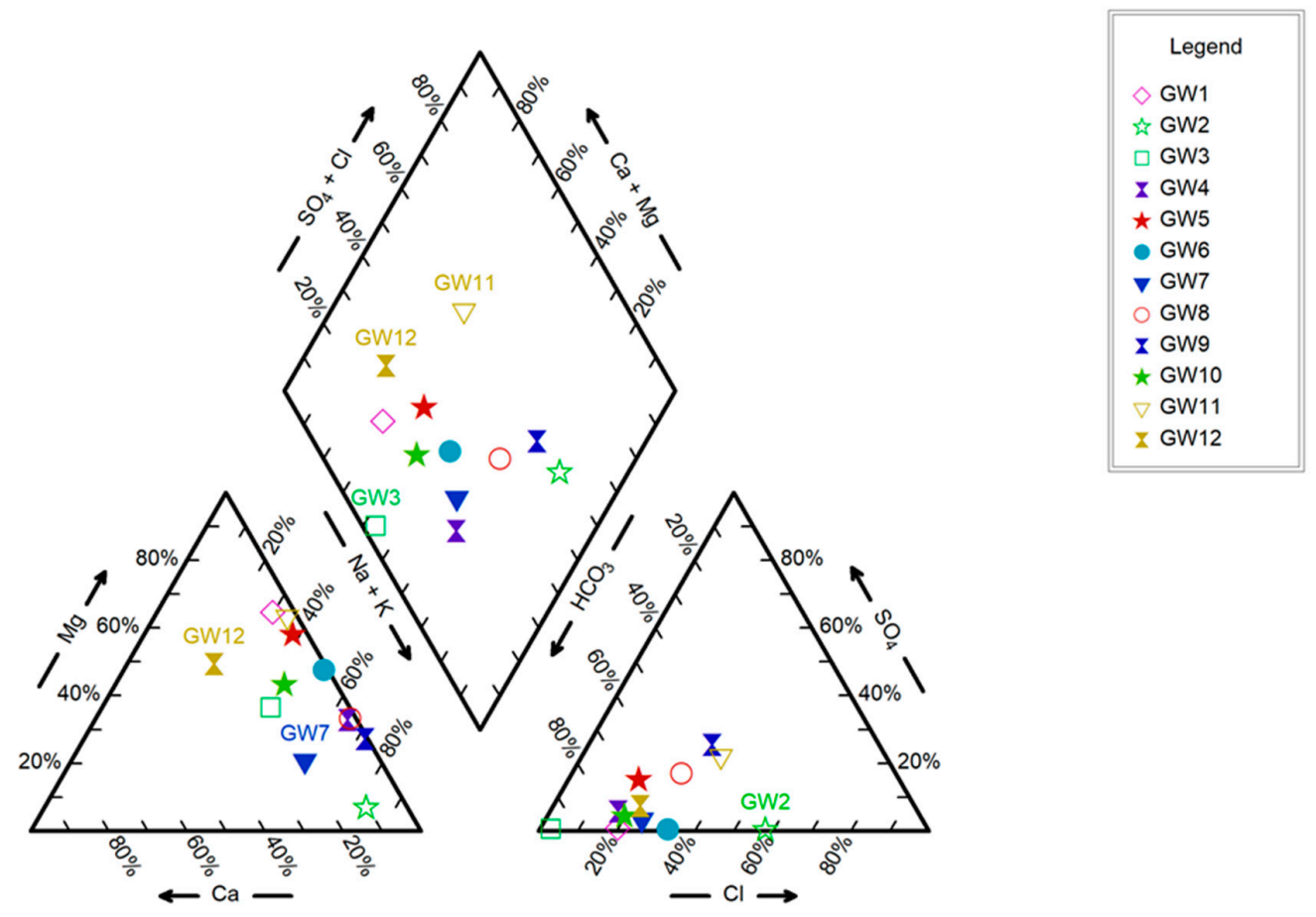

Figure 7. Piper diagram of 12 groundwater samples in the study area.

\subsection{Speciation Modelling for Selected Minerals}

Speciation modelling using the PHREEQC code [57] was performed to calculate the saturation index (SI) of selected minerals in the groundwater samples. The result is shown in Figure 8. A positive value of SI means water samples are saturated with respect to that mineral, while negative value indicates under-saturation of water samples with respect to those minerals. Here, six different minerals namely hydroxyapetite, fluorite, calcite, anhydrite, dolomite, and aragonite were selected which could possibly control the water chemistry in the study area. The results show that most of the groundwater samples are over-saturated with respect to the calcite, dolomite and aragonite minerals clearly depicting the source of $\mathrm{HCO}_{3}{ }^{-}$through carbonate weathering. Looking in fluoride and hydroxyapatite, it was found that water samples were normally under-saturated except for a few samples. Looking for the saturation index for anhydrite, it was found that all water samples were unsaturated with respect to this mineral, indicating that both $\mathrm{Ca}^{2+}$ and $\mathrm{SO}_{4}{ }^{2-}$ are not coming from anhydrite. Also, $\mathrm{SO}_{4}{ }^{2-}$ is mainly coming from anthropogenic sources rather than geogenic origin. 


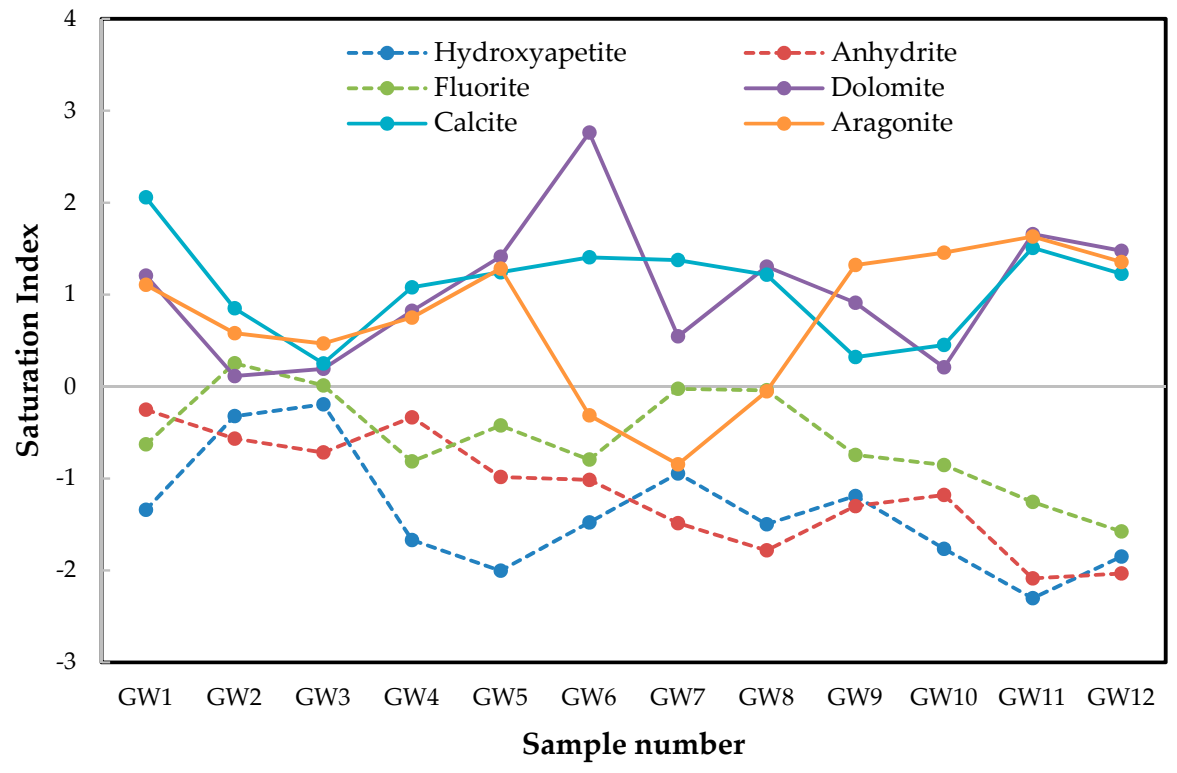

Figure 8. Saturation index for selected minerals related to fluoride in groundwater.

\subsection{Groundwater Quality Index}

WQI was calculated for groundwater samples. The results are shown in Figure 9 and Table A1. Computed WQI values ranged from 41.97 to 239.66 with an average value of 80.37 , which can be placed in four categories, namely very poor water (1), poor water (1), good water (5), and excellent water (5). Still, more than $80 \%$ of the water samples fell into the good and excellent water categories. The very poor water type of only one groundwater sample (i.e., GW5) is mainly due to the combined effect of relatively higher concentrations of TDS, EC, and $\mathrm{NO}_{3}{ }^{-}$as well as high salt values. Also, looking at GW7 and GW10, WQI values were 77.78 and 176.77, respectively. These are marginal values and are susceptible to worsening into the poor and very poor categories, respectively. Therefore, timely actions for their management is very much advisable.

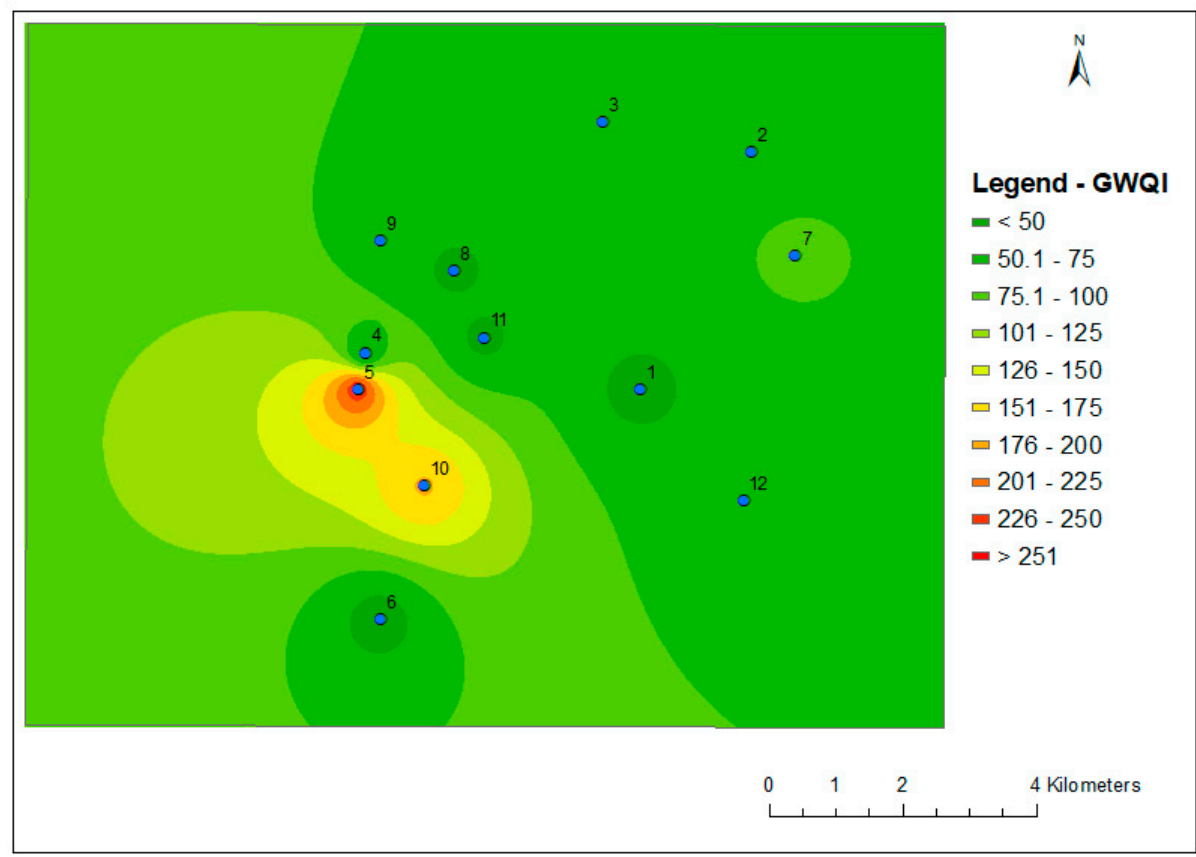

Figure 9. Spatial distribution of groundwater quality index (GWQI) using IDW interpolation in the study area. 


\subsection{Spatial Analysis of Groundwater Quality}

Cluster analysis was used in order to classify water quality and the pollution sources for different samples. Here, with regard to the dendrogram cross section, all groundwater samples were divided into three groups (Figure 10a,b). Cluster 1 includes four groundwater samples i.e., GW2, GW3, GW7, and GW12. Cluster 2 includes five samples i.e., GW1, GW4, GW6, GW8, and GW11. Finally, cluster 3 includes the rest of the three samples including GW5, GW9, and GW10. The first group, which has four samples, is characterized in terms of where water quality is mainly governed by vegetation, agricultural activities, and close vicinity to settlements. We can compare the locations of water samples and the LULC map shown in Figure 3. It can be seen that group 1 samples are near vegetation, agricultural activities, and in close vicinity to settlements. Similarly, looking into group 2 , water quality is mainly governed by hydro-chemical reactions going on both in agricultural land and mining areas, whereas water quality for group 3 is mainly being governed by hydrochemical processes going on in settlement areas.

(a) Dendrogram

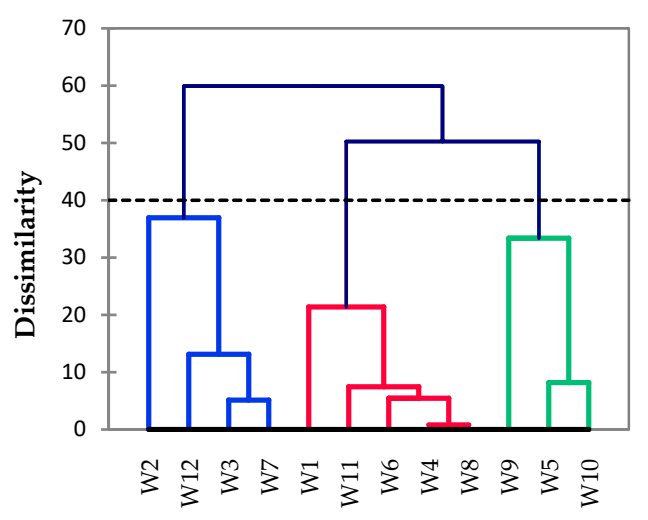

(b) Observations (axes F1 and F2: $100.00 \%$ )

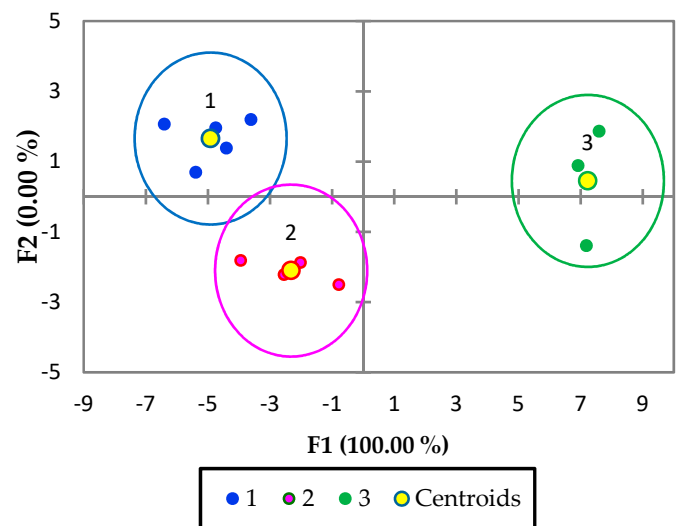

Figure 10. (a) Dendrogram showing spatial similarities of groundwater sampling locations using cluster analysis, (b) results from discriminant analysis crusted in 3 groups based on the distance metric. Ward agglomeration method and dissimilarity of euclidean distance was applied.

In addition to the dendrogram, similarities and dissimilarities among three groups were evaluated with the help of factor analysis. The result is shown in Figure 5. Here, the similarity distance among clusters indicates that the groundwater samples in different clusters with lesser gaps between them had similar characteristics with respect to groundwater quality due to the same background source and type of pollution sources. Results suggest that there is a significant difference between cluster 3 and the other clusters.

The result of PCA is shown in Figure 11. Here, both $x$ and $y$ axes represented by F1 and F2, explained $31.06 \%$ and $22.15 \%$ of the total variance, respectively. High variation for parameters like $\mathrm{pH}$, $\mathrm{EC}, \mathrm{TH}, \mathrm{CO}_{3}{ }^{2-}, \mathrm{HCO}_{3}{ }^{-}, \mathrm{K}^{+}, \mathrm{Si}$, and $\mathrm{Ca}^{2+}$ were reported. Cluster 1 groundwater samples normally have high $\mathrm{pH}, \mathrm{CO}_{3}{ }^{2-}$, $\mathrm{SS}$, and $\mathrm{K}$; whereas cluster 2 has higher values of $\mathrm{SS}, \mathrm{Si}$, and $\mathrm{CaH}$. Finally, cluster 3 has high $\mathrm{EC}, \mathrm{TDS}, \mathrm{CO}_{3}{ }^{2-}, \mathrm{HCO}_{3}{ }^{-}$, and $\mathrm{Si}$. 


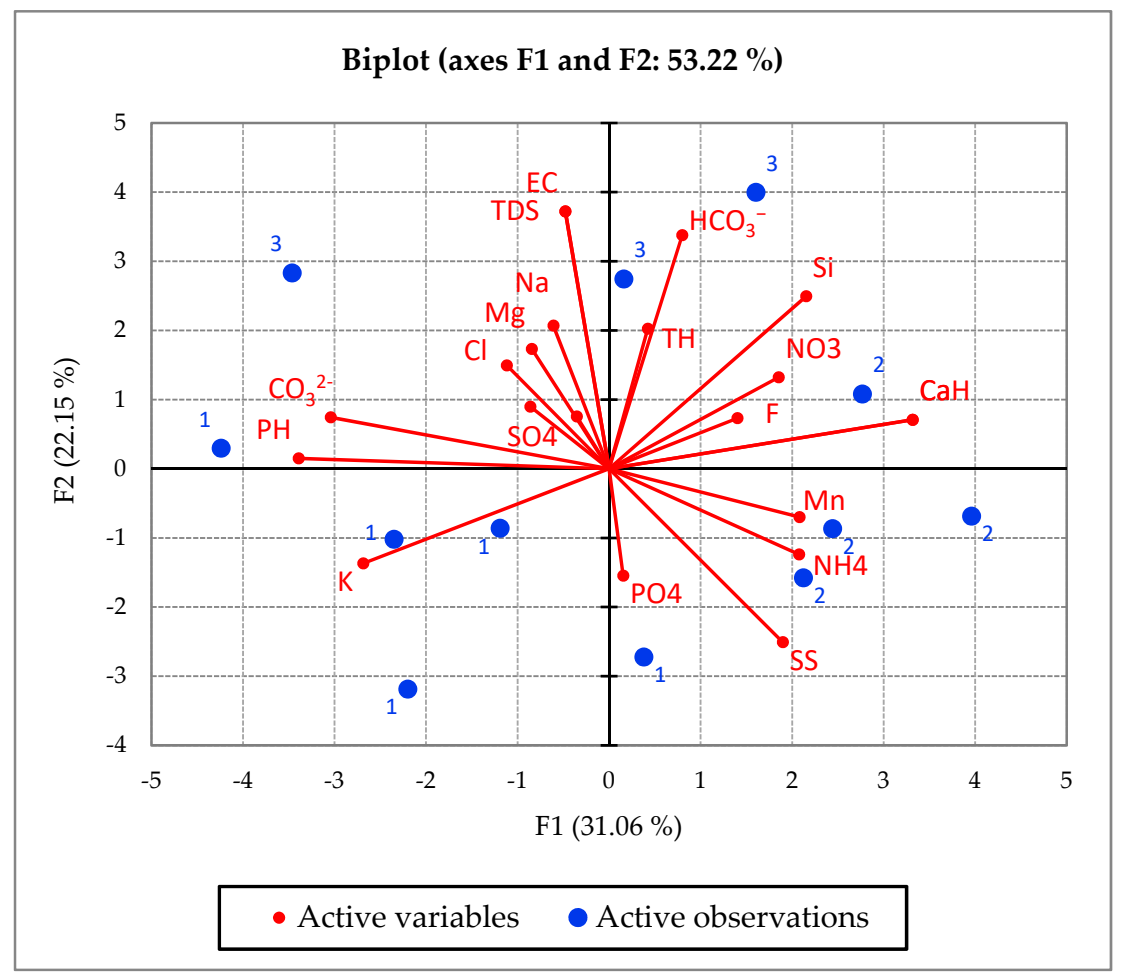

Figure 11. Result for biplot diagram for three clusters in the study area.

\section{Conclusions}

The integrated approach using statistical analysis, speciation modeling, and graphical analysis was applied to examine the hydrochemical characteristics of groundwater quality in the Mokopane area, South Africa. The study suggests that groundwater quality is in good condition, except for a few boreholes due to sporadic pollution from $\mathrm{F}^{-}$and $\mathrm{SO}_{4}{ }^{2-}$ in the study area. Mainly $\mathrm{F}^{-}$pollution is of major concern due to very high concentration at sporadic locations. Results of speciation modelling for six selected minerals also suggest that most of the groundwater samples are over-saturated with respect to the calcite, dolomite, and aragonite minerals clearly depicting the source of $\mathrm{HCO}_{3}{ }^{-}$through carbonate weathering. Looking into fluoride and hydroxyapatite, it was found that water samples are normally under-saturated except for few samples. The mineral composition as suggested by speciation modelling and the alkaline nature of groundwater supports the chemical reaction for fluoride enrichment through weathering. The depth profile of $\mathrm{SO}_{4}{ }^{2-}$ indicates that leaching of untreated sewage is the prime source of high $\mathrm{SO}_{4}{ }^{2-}$ concentration especially in shallow aquifers. Overall, both natural processes (i.e., rock-water interaction, silicate weathering) and poor management of anthropogenic activities (i.e., mining, leaching from untreated sewage and agricultural runoff) have a combined effect on the evolution of water quality. Computed WQI values suggest that more than $80 \%$ of the water samples fell into the good and excellent water categories. Although few samples stood in the poor and very poor categories and the water quality may further worsen if timely actions for their management are not taken. In summary, this study gives a snapshot of the status quo of water quality which is of high scientific merit despite being based on a small number of samples in the data-scarce region of Mokopane area. This study will be useful as a baseline for the planning of sustainable water resources management in the mining area in the near future to help in implementation of SDGs. The limitation of this study is the limited number of borehole samples for investigation. Hence, a detailed examination of water quality along with soil samples on a larger spatio-temporal scale can be a subject of future study.

Author Contributions: Conceptualization, M.D.M., R.A., P.K., H.V.T.M.; methodology, M.D.M., R.A., P.K., H.V.T.M.; investigation, D.M., R.A.; writing, M.D.M., R.A., P.K., H.V.T.M.; writing—review and editing, M.D.M., R.A., P.K., H.V.T.M., T.A.K. 
Funding: This research received no external funding.

Acknowledgments: The author is grateful to the Environmental Department of Ivanplats mine for providing data for this research paper, the Faculty of Environmental Earth Science (Hokkaido University) for facilities, and anonymous reviewers for their comments. The author further extends gratitude to the JICA ABE Initiative scholarship for the opportunity to study in Hokkaido University.

Conflicts of Interest: The authors declare no conflict of interest.

\section{Appendix A}

Table A1. Calculated water quality index (WQI) for each borehole water sample.

\begin{tabular}{ccc}
\hline Boreholes & WQI & Water Quality \\
\hline 1 & 43.18 & Excellent water \\
2 & 64.47 & Good water \\
3 & 66.85 & Good water \\
4 & 44.78 & Excellent water \\
5 & 239.66 & Very poor water \\
6 & 41.97 & Excellent water \\
7 & 77.78 & Good water \\
8 & 44.04 & Excellent water \\
9 & 63.76 & Good water \\
10 & 176.77 & Poor water \\
11 & 44.81 & Excellent water \\
12 & 56.34 & Good water \\
\hline
\end{tabular}

\section{References}

1. USGS. How Important Is Groundwater? Available online: https://www.usgs.gov/faqs/how-importantgroundwater?qt-News_science_products=0\#qt-news_science_products (accessed on 11 July 2019).

2. Avtar, R.; Tripathi, S.; Kumar Aggarwal, A. Assessment of Energy-Population-Urbanization Nexus with Changing Energy Industry Scenario in India. Land 2019, 8, 124. [CrossRef]

3. Avtar, R.; Tripathi, S.; Aggarwal, A.K.; Kumar, P. Population-Urbanization-Energy Nexus: A Review. Resources 2019, 8, 136. [CrossRef]

4. Ahmad, M.; Bastiaanssen, W.G.; Feddes, R. Sustainable use of groundwater for irrigation: A numerical analysis of the subsoil water fluxes. Irrig. Drain. J. Int. Comm. Irrig. Drain. 2002, 51, 227-241. [CrossRef]

5. Avtar, R.; Kharrazi, A. Exploring Renewable Energy Resources Using Remote Sensing and GIS-A Review. Resources 2019, 8, 149. [CrossRef]

6. Minh, H.V.T.; Avtar, R.; Kumar, P.; Tran, D.Q.; Ty, T.V.; Behera, H.C.; Kurasaki, M. Groundwater Quality Assessment Using Fuzzy-AHP in an Giang Province of Vietnam. Geosciences 2019, 9, 330. [CrossRef]

7. Minh, H.V.T.; Kurasaki, M.; Van Ty, T.; Tran, D.Q.; Le, K.N.; Avtar, R.; Rahman, M.; Osaki, M. Effects of Multi-Dike Protection Systems on Surface Water Quality in the Vietnamese Mekong Delta. Water 2019, 11, 1010. [CrossRef]

8. Le, N.K.; Jha, K.M.; Jeong, J.; Gassman, W.P.; Reyes, R.M.; Doro, L.; Tran, Q.D.; Hok, L. Evaluation of Long-Term SOC and Crop Productivity within Conservation Systems Using GFDL CM2.1 and EPIC. Sustainability 2018, 10, 2665. [CrossRef]

9. Zahedi, S. Modification of expected conflicts between Drinking Water Quality Index and Irrigation Water Quality Index in water quality ranking of shared extraction wells using Multi Criteria Decision Making techniques. Ecol. Indic. 2017, 83, 368-379. [CrossRef]

10. Neisi, A.; Mirzabeygi Radfard, M.; Zeyduni, G.; Hamzezadeh, A.; Jalili, D.; Abbasnia, A.; Yousefi, M.; Khodadadi, R. Data on fluoride concentration levels in cold and warm season in City area of Sistan and Baluchistan Province, Iran. Data Brief. 2018, 18, 713-718. [CrossRef]

11. Subramani, T.; Elango, L.; Damodarasamy, S.R. Groundwater quality and its suitability for drinking and agricultural use in Chithar River Basin, Tamil Nadu, India. Environ. Geol. 2005, 47, 1099-1110. [CrossRef] 
12. Avtar, R.; Kumar, P.; Singh, C.K.; Sahu, N.; Verma, R.L.; Thakur, J.K.; Mukherjee, S. Hydrogeochemical Assessment of Groundwater Quality of Bundelkhand, India Using Statistical Approach. Water Qual. Expo. Health 2013, 5, 105-115. [CrossRef]

13. Kumar, P.; Ram, A. Chapter 4: Integrating major ion chemistry with statistical analysis for geochemical assessment of groundwater quality in coastal aquifer of Saijo plain, Ehime prefecture, Japan. In Water Quality: Indicators, Human Impact and Environmental Health; Nova Publication: Haryana, India, 2013; pp. 99-108. ISBN 978-1-62417-111-6.

14. Avtar, R.; Kumar, P.; Surjan, A.; Gupta, L.; Roychowdhury, K. Geochemical processes regulating groundwater chemistry with special reference to nitrate and fluoride enrichment in Chhatarpur area, Madhya Pradesh, India. Environ. Earth Sci. 2013, 70, 1699-1708. [CrossRef]

15. Matthess, G. The Properties of Groundwater; Department of Earth Science, J. Wiley and Sons Inc.: New York, NY, USA, 1982; p. 406.

16. Kumar, P.; Kumar, M.; Ramanathan, A.L.; Tsujimura, M. Tracing the factors responsible for arsenic enrichment in groundwater of the middle Gangetic Plain, India: A source identification perspective. Environ. Geochem. Health 2010, 32, 129-146. [CrossRef] [PubMed]

17. Dat, T.Q.; Kanchit, L.; Thares, S.; Trung, N.H. Modeling the Influence of River Discharge and Sea Level Rise on Salinity Intrusion in Mekong Delta. In Proceedings of the 1st Environment Asia International Conference, Bangkok, Thailand, 23-26 March 2011; Volume 35, pp. 685-701.

18. Ty, T.V. Scenario-based Impact Assessment of Land Use/Cover and Climate Changes on Water Resources and Demand: A Case Study in the Srepok River Basin, Vietnam-Cambodia. Water Res. Manag. 2012, 26, 1387-1407. [CrossRef]

19. World Health Organization (WHO). Guidelines for Drinking-Water Quality, 3rd ed.; WHO: Geneva, Switzerland, 2006; Volume 1, Available online: http://www.who.int/water_sanitation_health/dwq/gdwq0506.pdf (accessed on 8 July 2019).

20. UNICEF. UNICEF Handbook on Water Quality; United Nations Childrens Fund: New York, NY, USA, 2008.

21. Alagumuthu, G.; Rajan, M. Chemometric studies of water quality parameters of Sankarankovil block of Tirunelveli, Tamilnadu. J. Environ. Biol. 2010, 31, 581-586.

22. Singh, C.K.; Rina, K.; Singh, R.; Shashtri, S.; Kamal, V.; Mukherjee, S. Geochemical modeling of high fluoride concentration in groundwater of Pokhran area of Rajasthan, India. Bull. Environ. Contam. Toxicol. 2011, 86, 152-158. [CrossRef] [PubMed]

23. Kumar, P.; Kumar, A.; Singh, C.K.; Saraswat, C.; Avtar, R.; Ramanathan, A.; Herath, S. Hydrogeochemical evolution and appraisal of groundwater quality in Panna District, Central India. Expo. Health 2016, 8, 19-30. [CrossRef]

24. Chapman, D.V. Water Quality Assessments: A Guide to the Use of Biota, Sediments and Water in Environmental Monitoring; CRC Press: Boca Raton, FL, USA, 1996; ISBN 0-419-21590-5.

25. Olajire, A.A.; Imeokparia, F.E. Water Quality Assessment of Osun River: Studies on Inorganic Nutrients. Environ. Monit. Assess. 2001, 69, 17-28. [CrossRef] [PubMed]

26. Vasanthavigar, M.; Srinivasamoorthy, K.; Prasanna, M.V. Evaluation of groundwater suitability for domestic, irrigational, and industrial purposes: A case study from Thirumanimuttar river basin, Tamilnadu, India. Environ. Monit. Assess. 2012, 184, 405-420. [CrossRef] [PubMed]

27. Hua, A.K. Land use land cover changes in detection of water quality: A study based on remote sensing and multivariate statistics. J. Environ. Public Health 2017, 2017. [CrossRef]

28. Khan, A.; Khan, H.H.; Umar, R. Impact of land-use on groundwater quality: GIS-based study from an alluvial aquifer in the western Ganges basin. Appl. Water Sci. 2017, 7, 4593-4603. [CrossRef]

29. Narany, T.S.; Aris, A.Z.; Sefie, A.; Keesstra, S. Detecting and predicting the impact of land use changes on groundwater quality, a case study in Northern Kelantan, Malaysia. Sci. Total Environ. 2017, 599, 844-853. [CrossRef] [PubMed]

30. Machiwal, D.; Cloutier, V.; Güler, C.; Kazakis, N. A review of GIS-integrated statistical techniques for groundwater quality evaluation and protection. Environ. Earth Sci. 2018, 77, 681. [CrossRef]

31. Gustafsson, P. High resolution satellite data and GIS as a tool for assessment of groundwater potential of semi-arid area. In Proceedings of the IXth Thematic Conference on Geologic Remote Sensing, Pasadena, CA, USA, 8-11 February 1993. 
32. Dabral, S.; Sharma, N. An Integrated Geochemical and Geospatial Approach for Assessing the Potential Ground Water Recharge Zones in Mahi-Narmada Inter Stream Doab Area, Gujarat, India. J. Environ. Earth Sci. 2013, 3, 134-144.

33. Demir, Y.; Erşahin, S.; Güler, M.; Cemek, B.; Günal, H.; Arslan, H. Spatial variability of depth and salinity of groundwater under irrigated ustifluvents in the Middle Black Sea Region of Turkey. Environ. Monit. Assess. 2009, 158, 279-294. [CrossRef] [PubMed]

34. Baalousha, H. Assessment of a groundwater quality monitoring network using vulnerability mapping and geostatistics: A case study from Heretaunga Plains, New Zealand. Agric. Water Manag. 2010, 97, 240-246. [CrossRef]

35. Dash, J.; Sarangi, A.; Singh, D. Spatial variability of groundwater depth and quality parameters in the national capital territory of Delhi. Environ. Manag. 2010, 45, 640-650. [CrossRef] [PubMed]

36. Abbasnia, A.; Yousefi, N.; Mahvi, A.H.; Nabizadeh, R.; Radfard, M.; Yousefi, M.; Alimohammadi, M. Evaluation of groundwater quality using water quality index and its suitability for assessing water for drinking and irrigation purposes: Case study of Sistan and Baluchistan province (Iran). Hum. Ecol. Risk Assess. Int. J. 2019, 25, 988-1005. [CrossRef]

37. Busari, O. Groundwater use in parts of the Limpopo Basin, South Africa. In Proceedings of the 3rd International Conference of Energy and Development-Environment-Biomedicine, Athens, Greece, 29-31 December 2009; pp. 13-18.

38. Statistics. South Africa Statistics. South Africa (Web) 2016. Available online: http://www.statssa.gov.za/ (accessed on 8 July 2019).

39. Climate Data. Climate Mokopane. Available online: https://en.climate-data.org/africa/south-africa/limpopo/ mokopane-953/ (accessed on 1 July 2019).

40. Mineral Council in South Africa. Chamber of Mines. Available online: https://www.mineralscouncil.org.za/ (accessed on 18 August 2019).

41. USGS. Platinum-Group Elements in Southern Africa-Mineral. Inventory and an Assessment of Undiscovered Mineral Resources; US Department of the Interior: Reston, VA, USA, 2010; p. 126.

42. Xin, X.; Li, K.; Finlayson, B.; Yin, W. Evaluation, prediction, and protection of water quality in Danjiangkou Reservoir, China. Water Sci. Eng. 2015, 8, 30-39. [CrossRef]

43. Minh, H.V.T.; Ngoc, D.T.H.; Ngan, H.Y.; Men, H.V.; Van, T.N.; Ty, T.V. Assessment of Groundwater Level and Quality: A Case Study in O Mon and Binh Thuy Districts, Can Tho City, Vietnam. Naresuan Univ. Eng. J. 2016, 11, 25-33.

44. Lever, J.; Krzywinski, M.; Altman, N. Principal component analysis. Nat. Methods 2017, 14, 641. [CrossRef]

45. Shrestha, S.; Kazama, F. Assessment of surface water quality using multivariate statistical techniques: A case study of the Fuji river basin, Japan. Environ. Model. Softw. 2007, 22, 464-475. [CrossRef]

46. Busico, G.; Cuoco, E.; Kazakis, N.; Colombani, N.; Mastrocicco, M.; Tedesco, D.; Voudouris, K. Multivariate statistical analysis to characterize/discriminate between anthropogenic and geogenic trace elements occurrence in the Campania Plain, Southern Italy. Environ. Pollut. 2018, 234, 260-269. [CrossRef] [PubMed]

47. Fetter, C.W. Applied Hydrogeology, 3rd ed.; Macmillan College Publishing Company: New York, NY, USA, 1994.

48. Garrels, R.M.; Christ, C.L. Solutions, Minerals, and Equilibria; Harper \& Row: New York, NY, USA, 1965.

49. Tiwari, T.; Mishra, M. A preliminary assignment of water quality index of major Indian rivers. Indian J. Environ. Prot. 1985, 5, 276-279.

50. Singh, S.; Hussian, A. Water quality index development for groundwater quality assessment of Greater Noida sub-basin, Uttar Pradesh, India. Cogent Eng. 2016, 3, 1177155. [CrossRef]

51. Fu, L.; Wang, Y.-G. Statistical Tools for Analyzing Water Quality Data. In Water Quality Monitoring and Assessment; InTech: London, UK, 2012; ISBN 978-953-51-0486-5.

52. Singh, C.K.; Shashtri, S.; Mukherjee, S.; Kumari, R.; Avatar, R.; Singh, A.; Singh, R.P. Application of GWQI to Assess Effect of Land Use Change on Groundwater Quality in Lower Shiwaliks of Punjab: Remote Sensing and GIS Based Approach. Water Res. Manag. 2011, 25, 1881-1898. [CrossRef]

53. Shepard, D. A two-dimensional interpolation function for irregularly-spaced data. In Proceedings of the 23rd ACM National Conference, Las Vegas, NV, USA, 27-29 August 1968; ACM: New York, NY, USA, 1968; pp. 517-524. 
54. Bartier, P.M.; Keller, C.P. Multivariate interpolation to incorporate thematic surface data using inverse distance weighting (IDW). Comput. Geosci. 1996, 22, 795-799. [CrossRef]

55. Geographic Information Technology Tranning Alliance Distance-Based Interpolation. Available online: http: //www.gitta.info/ContiSpatVar/en/html/Interpolatio_learningObject2.xhtml (accessed on 4 September 2019).

56. Subramanian, V.; Saxena, K. Hydrogeochemistry of groundwater in the Delhi region of India. In Proceedings of the Hamburg Symposium, Hamburg, Germany, 18-19 August 1983.

57. Parkhurst, D.L.; Appelo, C. User's guide to PHREEQC (Version 2): A computer program for speciation, batch-reaction, one-dimensional transport, and inverse geochemical calculations. Water Resour. Investig. Rep. $1999,99,312$.

(c)

(C) 2019 by the authors. Licensee MDPI, Basel, Switzerland. This article is an open access article distributed under the terms and conditions of the Creative Commons Attribution (CC BY) license (http://creativecommons.org/licenses/by/4.0/). 